pyramidal signs. Delayed myelopathy has been described as a complication of severe electrical burns. ${ }^{4}$ Spastic paraplegia ${ }^{5}$ and quadriplegia have been recorded secondary to electrical injury but not after lightning injury. We ascribe the delay of 36 hours before the onset of symptoms in our patient to oedema of the spinal cord.

We thank Mr Richard Baker, of The Royal Northern Infirmary, Inverness, for permission to report this case, and Dr Mary Corbett, of the Middlesex Hospital, for help with the manuscript.

${ }^{1}$ Critchley, MacDonald, Lancet, 1934, 1, 68.

2 British Medical fournal, 1974, 4, 181.

${ }^{3}$ Strasser, E J, Davis, M, and Menchey, M J, fournal of Trauma, 1977, 17, 315.

${ }^{4}$ Holbrook, L A, Beach, F X M, and Silver, J R, British Medical fournal, 1970, 4, 659.

5 DiVincenti, F C, et al, fournal of Trauma, 1974, 9, 497.

(Accepted 12 September 1978)

Department of Rheumatology, Middlesex Hospital, London W1

M SHARMA, MRCP, locum senior registrar (now associate, Department of Rheumatology, The Hahnemann Medical College and Hospital of Philadelphia, Philadelphia, Pennsylvania 19102, USA)

\section{Amanita phalloides poisoning treated by early charcoal haemoperfusion}

Treatment of Amanita phalloides poisoning remains disappointing. Prednisone, thioctic acid, vitamin $\mathrm{C}$, penicillin, cytochrome-C, and haemodialysis alone or in combination have been used with variable success. ${ }^{2}$ Perfusion of blood over coated activated charcoal has also been tried in a few cases, but always after the onset of acute liver failure. ${ }^{34}$ We have used charcoal haemoperfusion as early as possible after the ingestion of $A$ phalloides to try to fix the toxins before they caused hepatic or renal damage.

\section{Patients, methods, and results}

Four men and four women, aged 16 to 55 , were admitted to the emergency room. All had eaten mushrooms 16 hours earlier. Seven had eaten more than three-a supposedly lethal quantity. They all had severe gastrointestinal symptoms. There were no clinical or biochemical signs of hepatic failure (serum alanine transaminase (serum ALT; SGPT) concentration $<40 \mathrm{IU} / 1$, blood ammonia $<45 \mu \mathrm{g} / 100 \mathrm{ml}(32 \mu \mathrm{mol} / \mathrm{l})$ ). The mushrooms remaining after the meal were identified as $A$ phalloides. All the patients except the one who had eaten only a small amount were treated by haemoperfusion. In three patients this was started immediately. In the remainder it was begun a few hours after an initial dialysis. All patients were given penicillin 1000000 $\mathrm{U}$ hourly and vitamin $\mathrm{C} 1 \mathrm{~g}$ six-hourly intravenously. Each haemoperfusion lasted three hours, and they were continued daily until there was clinical and biochemical improvement. One patient had five haemoperfusions, one had four, three had three each, and two patients had two each.

There were no technical problems. Platelet counts dropped during most of the perfusions to a mean of $80 \%$ of the starting value. The lowest count observed after one hour of haemoperfusion was $76 \cdot 10^{9} / 1\left(76000 / \mathrm{mm}^{3}\right)$. White blood cell counts did not change. The clinical course in each case was uneventful. Vomiting and diarrhoea subsided within 24 to 36 hours. No clinical signs of liver failure were observed, even in the two patients with high AL $T$ concentrations. Four of the patients left hospital after three days. The gastrointestinal symptoms in the patient who was not haemoperfused were more severe and lasted longer than those in any of the others. Serum ALT concentrations responded in two different ways (table). In two patients they rose to 1920 and $310 \mathrm{IU} 1$ on the third day. In the remainder there were only slight and transient rises. Changes in aspartate transaminase (AST; SGOT) concentrations closely paralleled those of ALT. In contrast, in all eight patients there were sharp changes in blood urea nitrogen (BUN) and blood ammonia concentrations. BUN fell from $21 \cdot 5 \pm 1 \cdot 1 \mathrm{mg} / 100 \mathrm{ml}(7 \cdot 6 \pm 0 \cdot 4$ mmol/1) to reach its lowest level of $3.5 \pm 0.8 \mathrm{mg} / 100 \mathrm{ml}(1.2 \pm 0.2 \mathrm{mmol} / \mathrm{l})$ (mean + SEM) on day four, while blood ammonia concentrations rose from $34.9 \pm 2 \cdot 9 \mu \mathrm{g} / 100 \mathrm{ml}(25 \cdot 9 \pm 2 \cdot 1 \mu \mathrm{mol} / \mathrm{l})$ to $56 \pm 3 \cdot 9 \mu \mathrm{g} / 100 \mathrm{ml}(42 \cdot 1 \pm 2 \cdot 7$ $\mu \mathrm{mol} / \mathrm{l})$. These changes, suggestive of impaired hepatic synthesis activity,
Serum alanine transaminase (serum $A L T ; S G P T$ ) concentrations $(I U / l)$ in eight patients with mushroom ( $A$ phalloides) poisoning

\begin{tabular}{|c|c|c|c|c|c|c|c|c|c|}
\hline \multirow{2}{*}{$\begin{array}{l}\text { Day } \\
\text { No }\end{array}$} & \multicolumn{8}{|c|}{ Case No: } & \multirow{2}{*}{ Mean $\perp S E M$} \\
\hline & 1 & 2 & 3 & 4 & 5 & 6 & 7 & 8 & \\
\hline 1 & 51 & 15 & & & 10 & & 5 & & \\
\hline 2 & 179 & 180 & 33 & 8 & 18 & 7 & 6 & 8 & $55+27$ \\
\hline 3 & 1920 & 312 & 17 & 24 & 18 & 6 & 6 & 8 & $289 \pm 236$ \\
\hline 4 & 990 & 142 & 14 & 5 & 9 & 5 & 4 & 4 & $147 \pm 122$ \\
\hline 5 & 600 & 105 & 31 & 10 & 10 & 3 & 6 & 19 & $98 \pm 73$ \\
\hline 6 & 460 & 76 & 47 & 29 & 10 & 8 & 12 & 11 & $82=55$ \\
\hline 7 & 360 & 65 & 48 & 33 & 8 & 14 & 14 & 4 & $68 \pm 42$ \\
\hline $\begin{array}{l}8 \\
9\end{array}$ & 265 & & 32 & & & 30 & 13 & & \\
\hline 10 & 105 & 40 & 22 & & 30 & 27 & 14 & & $40=14$ \\
\hline 11 & 60 & 20 & & & & & & & \\
\hline
\end{tabular}

were confirmed by a fall in serum cholesterol to $116 \pm 11 \mathrm{mg} / 100 \mathrm{ml}(3 \cdot 0 \pm 0 \cdot 2$ $\mathrm{mmol} / \mathrm{l}$ ) and a prolonged thromboplastin time (quick level $55 \%$ of normal value) four days after ingestion. The following serum concentrations remained unchanged: alkaline phosphatase, bilirubin, lactic and pyruvic acid, fibrinogen, coagulation factors V, VII, and X, calcium, and creatinine. Follow-up examination two months later showed no sequelae in any of the patients.

\section{Comment}

Since there was no way of measuring the dose of toxin we could not know whether it was lethal. But all except one patient had eaten more than three mushrooms ( $>50 \mathrm{~g}$ ), which is generally accepted as a lethal dose. The wife of one patient (case 2), who had also taken the meal, was treated in another hospital by exchange transfusion and peritoneal dialysis. She was in hepatic coma for eight days, with serum ALT concentrations of $4000 \mathrm{IU} / 1$, and remained in hospital for more than three months. Her husband, who had eaten the same quantity and was treated by early haemoperfusion, left hospital after six days. Seeger and Bartels have since reported that in-vitro charcoal haemoperfusion removes alpha-amanitine from water and protein solutions. ${ }^{5}$ Our cases provide strong circumstantial evidence that charcoal can effectively remove toxins from the blood even 24 hours after eating $A$ phalloides. Further clinical trials of charcoal haemoperfusion seem justified.

We thank Dr H R Brunner for his critical review of this report.

${ }^{1}$ Lancet, 1972, 1, 1320.

2 Paaso, B, and Harrison, D C, American fournal of Medicine, 1975, 58, 505.

${ }^{3}$ Gazzard, B G, et al, Lancet, 1974, 1, 1301.

${ }^{4}$ Bartels, O, et al, Deutsche medizinische Wochenschrift, 1975, 48, 2509.

${ }^{5}$ Seeger, R, and Bartels, O, Deutsche medizinische Wochenschrift, 1976, 40, 1456.

(Accepted 20 September 1978)

Department of Medecine, Hôpital Cantonal Universitaire, Geneva, Switzerland

J P WAUTERS, MD, chef de travaux (present address: Division de

Néphrologie, Centre Hospitalier Universitaire, Lausanne, Switzerland) C ROSSEL, MD, chef de clinique

J J FARQUET, MD, chef de clinique

\section{Effect of}

\section{4,25-dihydroxycholecalciferol on calcium absorption in proximal small intestine in uraemia}

In patients who have undergone nephrectomy and patients with chronic renal failure the available 25 -hydroxycholecalciferol is preferentially converted to $24 \mathrm{R}, 25$-dihydroxycholecalciferol (24R, $\left.25(\mathrm{OH})_{2} \mathrm{D}_{3}\right)$, the biological activity of which is uncertain, rather than to $1 \propto, 25$-dihydroxycholecalciferol $\left(1,25-(\mathrm{OH})_{2} \mathrm{D}_{3}\right)$, the most potent hormonally active form of vitamin $\mathrm{D}_{3}$. Despite the generally suppressed production of both $1,25-(\mathrm{OH})_{2} \mathrm{D}_{3}$ and $24 \mathrm{R}, 25-(\mathrm{OH})_{2} \mathrm{D}_{3}$, which is reflected by, respectively, their absence ${ }^{1}$ or low plasma 
concentrations, ${ }^{2}$ the patients continue to absorb appreciable amounts of calcium from the gut.

Kanis et $a l^{3}$ reported recently that $24 \mathrm{R}, 25-(\mathrm{OH})_{2} \mathrm{D}_{3}$ at low daily doses increased intestinal absorption of calcium in anephric subjects and patients with advanced chronic renal failure, as measured by total body counter. The method reflects absorption throughout the entire intestine and does not discriminate between active transport and passive diffusion. On the other hand, Walling et $a l^{4}$ reported that in nephrectomised rats the duodenal, largely active, transport response was equivalent for equimolar doses of either $1,25-(\mathrm{OH})_{2} \mathrm{D}_{3}$ or $1 \alpha, 24,25$-trihydroxycholecalciferol while for $24 \mathrm{R}, 25-(\mathrm{OH})_{2} \mathrm{D}_{3}$ it was none. We decided therefore to find out whether $24 \mathrm{R}, 25-(\mathrm{OH})_{2} \mathrm{D}_{3}$ stimulates absorption in the proximal small intestine in man.

\section{Patients, methods and results}

Twelve patients with chronic renal failure who were not undergoing dialysis were investigated. None had been treated with vitamin $\mathrm{D}$. For two months six patients were each given $1.3 \mu \mathrm{g}$ daily of $24 \mathrm{R}, 25-(\mathrm{OH})_{2} \mathrm{D}_{3}$ and the other six $1.0 \mu \mathrm{g}$ daily of $1 \alpha$-hydroxy vitamin $\mathrm{D}_{3}\left(1 \alpha-\mathrm{OHD}_{3}\right)$. Before and immediately after treatment serum and urinary calcium, phosphorus, and creatinine were measured. Intestinal calcium absorption was measured by concurrent use of oral and intravenous calcium tracers and calculation by deconvolution, as described by Szymendera $e t a l^{5}$ but modified in that the oral dose of the tracer was given with $198 \mathrm{mg}$ of calcium carrier as glucoheptonate instead of a test breakfast. This method, whose reproducibility exceeds $94 \%$, measures absorption in the proximal small intestine, where calcium is taken up largely by active transport.

The table summarises the results. After small doses of $24 \mathrm{R}, 25-(\mathrm{OH})_{2} \mathrm{D}$ the absorption increased in two patients, remained unchanged in two, and fell in two patients. Thus, the observed differences of paired results represented the natural variability, and the mean change $( \pm S D), 2 \cdot 20 \pm 3 \cdot 56 \%$ of the test dose, was not significantly different from zero.

The other agent, $1 \alpha-\mathrm{OHD}_{3}$, failed to act in one patient with polycystic kidneys but increased the intestinal absorption of calcium in the remaining five patients, who had chronic glomerulonephritis. This response was significant by the Wilcoxon signed rank test $(P<0.05$, one tail). The increased absorption was accompanied by a rise in the serum concentration and urinary excretion of calcium. These related changes were significant $(P<0 \cdot 05)$.

\section{Comment}

Our results show that treatment of uraemic patients with small doses of $1 \alpha-\mathrm{OHD}_{3}$ increased calcium absorption in the proximal small intestine and in turn raised serum calcium concentrations and the urinary excretion of calcium. These results are presented merely to show that the applied test showed changes that occurred after administration of an agent known to be active in chronic renal failure.

On the other hand, $24 \mathrm{R}, 25-(\mathrm{OH})_{2} \mathrm{D}_{3}$ had no demonstrable effect on calcium absorption tested in this way. Thus, our results agree with those of Walling et $a l^{4}$ in that $24 \mathrm{R}, 25-(\mathrm{OH})_{2} \mathrm{D}_{3}$ does not stimulate active calcium transfer in duodenum and proximal jejunum. The mode of action of this vitamin $\mathrm{D}_{3}$ metabolite on calcium absorption therefore remains to be elucidated.

We thank Dr Milan Uskokovic of Hoffman-LaRoche for providing the $24,25-(\mathrm{OH})_{2} \mathrm{D}_{3}$ preparation. This work was supported by a research grant PR-6/0209 from the Polish National Cancer Programme.

${ }^{1}$ Haussler, M R, et al, in Vitamin D. Biochemical, Chemical and Clinical Aspects related to Calcium Metabolism, ed A W Norman et al, p 473. Berlin, DeGruyter, 1977.
2 Taylor, C M, in Vitamin D. Biochemical, Chemical and Clinical Aspects related to Calcium Metabolism, ed A W Norman et al, p 541. Berlin, DeGruyter, 1977.

${ }^{3}$ Kanis, J A, et al, British Medical fournal, 1978, 1, 1382.

${ }^{4}$ Walling, M W, et al, Archives of Biochemistry and Biophysics, 1977, 182, 251 .

${ }^{5}$ Szymendera, J, Heaney, R P and Saville, P D, fournal of Laboratory and Clinical Medicine, 1972, 79, 570.

(Accepted 15 September 1978)

Department of Nuclear Medicine, Maria Skłodowska-Curie

Memorial Institute of Oncology, 00-973 Warsaw

J SZYMENDERA, MD, DSC, associate professor and head of department

First Department of Internal Medicine, School of Medicine, 02-006 Warsaw, Poland

K GALUS, MD, DSC, assistant professor

\section{Social class, smoking, and obesity}

Previous studies of the effects of smoking on obesity in British men have been based on surveys of either predominantly social classes III, IV, and $\mathrm{V}^{1}$ or classes I and II. ${ }^{23}$ In the former, smokers were con- $\mathrm{O}$ sistently less obese than the non-smokers, though the smallest N difference between smokers and non-smokers was in the small proportion of the sample in classes I and II. ${ }^{1}$ In the surveys of mainly upper class men there was no difference between smokers and non-smokers. ${ }^{23}$ We have studied the relationship between smoking and obesity in working populations in North-west London with an adequate proportion of members of classes I and II as well as of III, IV, and V. Data on women as well as on men are available.

\section{Methods and results}

Information on age, social class, and smoking habits was obtained from 1339 men (aged 18-64) and 582 women (aged 18-59) interviewed during a study of ischaemic heart disease. ${ }^{4}$ Smokers were defined as those regularly smoking at least one cigarette, cigar, or pipe a day. The obesity index of weight $/$ height $^{2}\left(\mathrm{~kg} / \mathrm{m}^{2}\right)$ was used (weight in standard light gown; height without shoes). Skinfold thicknesses were measured at forearm, triceps, subscapular, and suprailiac sites. In both sexes there was a lower proportion of smokers and higher proportion of non-smokers in classes I/II than in IV/V.

The results (figure) showed that in men in classes I/II smokers were significantly more obese than non-smokers (smokers mean $( \pm \mathrm{SD}) \mathrm{W} / \mathrm{H}^{2}=$ $25 \cdot 1 \pm 2 \cdot 77$; non-smokers mean $\mathrm{W} / \mathrm{H}^{2}=23 \cdot 8 \pm 2 \cdot 73$ ). In classes $\mathrm{IV} / \mathrm{V}$ the reverse was seen (smokers mean $\mathrm{W} / \mathrm{H}^{2}=24 \cdot 7 \pm 3 \cdot 46$; non-smokers mean $\mathrm{W} / \mathrm{H}^{2}=26 \cdot 3 \pm 3 \cdot 76$ ). There was no difference in class III (smokers mean $\mathrm{W} / \mathrm{H}^{2}=24 \cdot 8 \pm 3 \cdot 15$; non-smokers mean $\left.\mathrm{W} / \mathrm{H}^{2}=24 \cdot 8 \pm 3 \cdot 40\right)$. Ex-smokers (not shown in figure) were significantly more obese than smokers in all classes $(\mathrm{P}<0.05)$. In women there were no significant differences in $\mathrm{W} / \mathrm{H}^{2}$ between smokers and non-smokers in classes $\mathrm{I} / \mathrm{II}$ (smokers mean $\mathrm{W} / \mathrm{H}^{2}=$ $23 \cdot 1 \pm 2 \cdot 77$; non-smokers mean $\mathrm{W} / \mathrm{H}^{2}=24 \cdot 0 \pm 3 \cdot 48$ ) or class III (smokers mean $\mathrm{W} / \mathrm{H}^{2}=24 \cdot 4 \pm 4.00$; non-smokers mean $\left.\mathrm{W} / \mathrm{H}^{2}=24 \cdot 5 \pm 4 \cdot 04\right)$. In classes IV/V, however, non-smokers were more obese than smokers (smokers mean $\mathrm{W} / \mathrm{H}^{2}=24 \cdot 1 \pm 3 \cdot 86$; non-smokers mean $\left.\mathrm{W} / \mathrm{H}^{2}=25 \cdot 8 \pm 2 \cdot 37\right)$. Exsmokers (not shown in figure) were significantly more obese than smokers

Responses of uraemic patients to two-months' treatment with $24 \mathrm{R}, 25-(\mathrm{OH})_{2} \mathrm{D}_{3}$ or $1 \alpha-O \mathrm{HD}_{3}$

\begin{tabular}{|c|c|c|c|c|c|c|c|c|c|c|c|}
\hline \multirow{2}{*}{$\begin{array}{l}\text { Case } \\
\text { No }\end{array}$} & \multicolumn{2}{|c|}{$\begin{array}{l}\text { Plasma creatinine } \\
(\mu \mathrm{mol} / \mathrm{l})\end{array}$} & \multicolumn{3}{|c|}{$\begin{array}{c}\text { Calcium absorption } \\
(\% \text { oral dose })\end{array}$} & \multicolumn{3}{|c|}{$\begin{array}{l}\text { Plasma calcium } \\
(\mathrm{mmol} / \mathrm{l})\end{array}$} & \multicolumn{3}{|c|}{$\begin{array}{l}\text { Urinary calcium } \\
\text { (mmol/day) }\end{array}$} \\
\hline & Before & After & Before & After & Difference & Before & After & Difference & Before & After & Difference \\
\hline \multicolumn{12}{|c|}{ Responses to $24 \mathrm{R}, 25-(\mathrm{OH})_{2} \mathrm{D}_{3}$} \\
\hline $\begin{array}{l}1 \\
2 \\
3 \\
4 \\
5 \\
6\end{array}$ & $\begin{array}{r}1255 \\
1273 \\
884 \\
1096 \\
707 \\
583\end{array}$ & $\begin{array}{r}1361 \\
1202 \\
1140 \\
1052 \\
1008 \\
610\end{array}$ & $\begin{array}{r}8 \cdot 25 \\
23 \cdot 07 \\
12 \cdot 34 \\
5 \cdot 72 \\
14 \cdot 06 \\
9 \cdot 76\end{array}$ & $\begin{array}{r}8 \cdot 24 \\
24 \cdot 28 \\
7 \cdot 55 \\
14 \cdot 34 \\
3 \cdot 80 \\
28 \cdot 19\end{array}$ & $\begin{array}{c}0 \\
0 \\
-\quad 4 \cdot 8 \\
+\quad 8 \cdot 6 \\
-10 \cdot 3 \\
+18.4\end{array}$ & $\begin{array}{l}1 \cdot 82 \\
2 \cdot 02 \\
2 \cdot 42 \\
2 \cdot 12 \\
2 \cdot 40 \\
2 \cdot 10\end{array}$ & $\begin{array}{l}1.77 \\
2.02 \\
2.52 \\
2.37 \\
1.97 \\
2.25\end{array}$ & $\begin{array}{l}-0.05 \\
0 \\
+0 \cdot 10 \\
+0.25 \\
-0.43 \\
+0.15\end{array}$ & $\begin{array}{l}1 \cdot 9 \\
2 \cdot 6 \\
2 \cdot 0 \\
2 \cdot 0 \\
1 \cdot 6 \\
3 \cdot 6\end{array}$ & $\begin{array}{l}1 \cdot 7 \\
2 \cdot 7 \\
2 \cdot 9 \\
2 \cdot 8 \\
1 \cdot 5 \\
4 \cdot 1\end{array}$ & $\begin{array}{l}-0.2 \\
+0.1 \\
+0.9 \\
+0.8 \\
-0.1 \\
+0.5\end{array}$ \\
\hline \multicolumn{12}{|c|}{ Responses to $1 \alpha-O H D_{3}$} \\
\hline $\begin{array}{r}7 \\
8 \\
9 \\
10 \\
11 \\
12\end{array}$ & $\begin{array}{l}707 \\
619 \\
566 \\
469 \\
380 \\
318\end{array}$ & $\begin{array}{l}884 \\
716 \\
619 \\
513 \\
495 \\
283\end{array}$ & $\begin{array}{r}9.90 \\
19.21 \\
14.59 \\
26.01 \\
13.65 \\
23.30\end{array}$ & $\begin{array}{l}15 \cdot 00 \\
83 \cdot 15 \\
19 \cdot 18 \\
40 \cdot 51 \\
51 \cdot 00 \\
23.09\end{array}$ & $\begin{array}{l}+5.1 \\
+63.9 \\
+\quad 4 \cdot 6 \\
+14.5 \\
+37 \cdot 4 \\
0\end{array}$ & $\begin{array}{l}1 \cdot 80 \\
2 \cdot 40 \\
2 \cdot 25 \\
1.92 \\
2 \cdot 50 \\
2 \cdot 25\end{array}$ & $\begin{array}{l}2 \cdot 02 \\
2 \cdot 52 \\
2 \cdot 40 \\
2 \cdot 22 \\
2 \cdot 64 \\
2 \cdot 45\end{array}$ & $\begin{array}{l}+0.22 \\
+0 \cdot 12 \\
+0 \cdot 15 \\
+0.30 \\
+0.14 \\
+0.20\end{array}$ & $\begin{array}{l}2 \cdot 7 \\
1.9 \\
1 \cdot 6 \\
2 \cdot 4 \\
2 \cdot 4 \\
1.8\end{array}$ & $\begin{array}{l}3 \cdot 3 \\
3 \cdot 2 \\
2 \cdot 1 \\
2 \cdot 9 \\
4 \cdot 0 \\
1 \cdot 8\end{array}$ & $\begin{array}{l}+0.6 \\
+1.3 \\
+0.5 \\
+0.5 \\
+1.6 \\
0\end{array}$ \\
\hline
\end{tabular}

Conversion: SI to traditional units-Creatinine: $100 \mu \mathrm{mol} / 1=1.13 \mathrm{mg} / 100 \mathrm{ml}$. Calcium: $1 \mathrm{mmol} / \mathrm{l}=4 \mathrm{mg} / 100 \mathrm{ml} ; 1 \mathrm{mmol} / \mathrm{day}=40 \mathrm{mg} / \mathrm{day}$. 